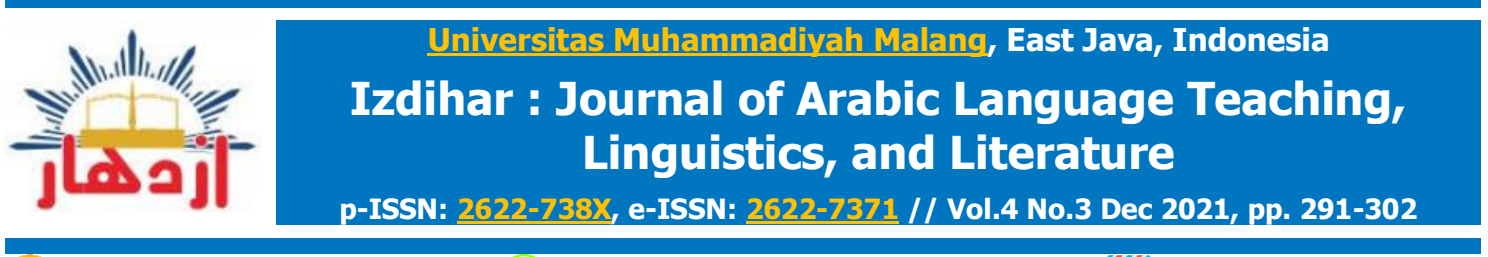

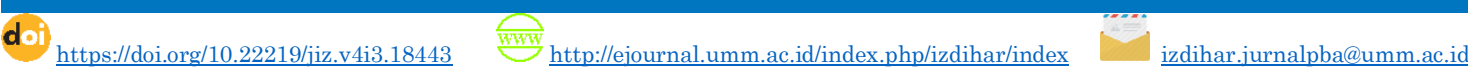

\title{
Lesson Plan Needs for Arabic Essay Writing (Kitabah Hurrah) Using Common European Framework of Reference for Language
}

\section{Muhammad Kamal bin Abdul Hakima, ${ }^{\text {, Syamsi Setiadi }}{ }^{\text {, } 2 \text {, Shafruddin Tajuddin }}{ }^{c, 3}$ Achmad Yanid, 4 \\ a, b, CUniversitas Negeri Jakarta, Indonesia dUniversiti Islam Sultan Sharif Ali, Brunei Darusalam \\ 11m.kamal.ah@unj.ac.id, 22syamsi.setiadi@unj.ac.id, 3shafruddin.ta@unj.ac.id, 4achmad.yani@unissa.edu.bn}

\section{ARTICLE INFO}

\section{Article History:}

Received: 22/10/2021

Revised: $25 / 11 / 2021$

Accepted: $31 / 12 / 2021$

Published: $31 / 12 / 2021$

\section{*Corresponding}

Author:

Name:

Muhammad Kamal bin Abdu

Hakim

Email: m.kamal.ah@unj.ac.id

\section{Keyword}

\section{ABSTRACT}

The lesson plan was a stage of instruction that regulates learning activities in the classroom that can have a positive impact on students' abilities in certain subjects. The purpose of this study was to identify the need for lesson plans in essay writing courses through the Common European Framework of Reference for Languages. The study used a qualitative approach through the descriptive method. Participants were students in the 3rd semester of 2020/2021 and lecturer. It was conducted in Arabic Language Education at the State University of Jakarta. Data is taken from the document, interview, and questionnaire. The data analysis process used data reduction, data display, and taking a conclusion. The results show that the lesson plans that have been made still have weaknesses and do not meet the Arabic language mastery standards from the Common European Framework of Reference for Languages (CEFR) standards. However, the results of the study have implications for the level of understanding of the lecturer related to the concept of a lesson plan that must be designed to suit the needs of students, the current situation, and also students' understanding of each mastery of the material being studied.

Copyright (c) 2021, Hakim et al

This is an open access article under the CC-BY-SA license

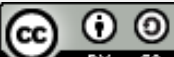

CEFR; Essay Writing; Lesson Plan

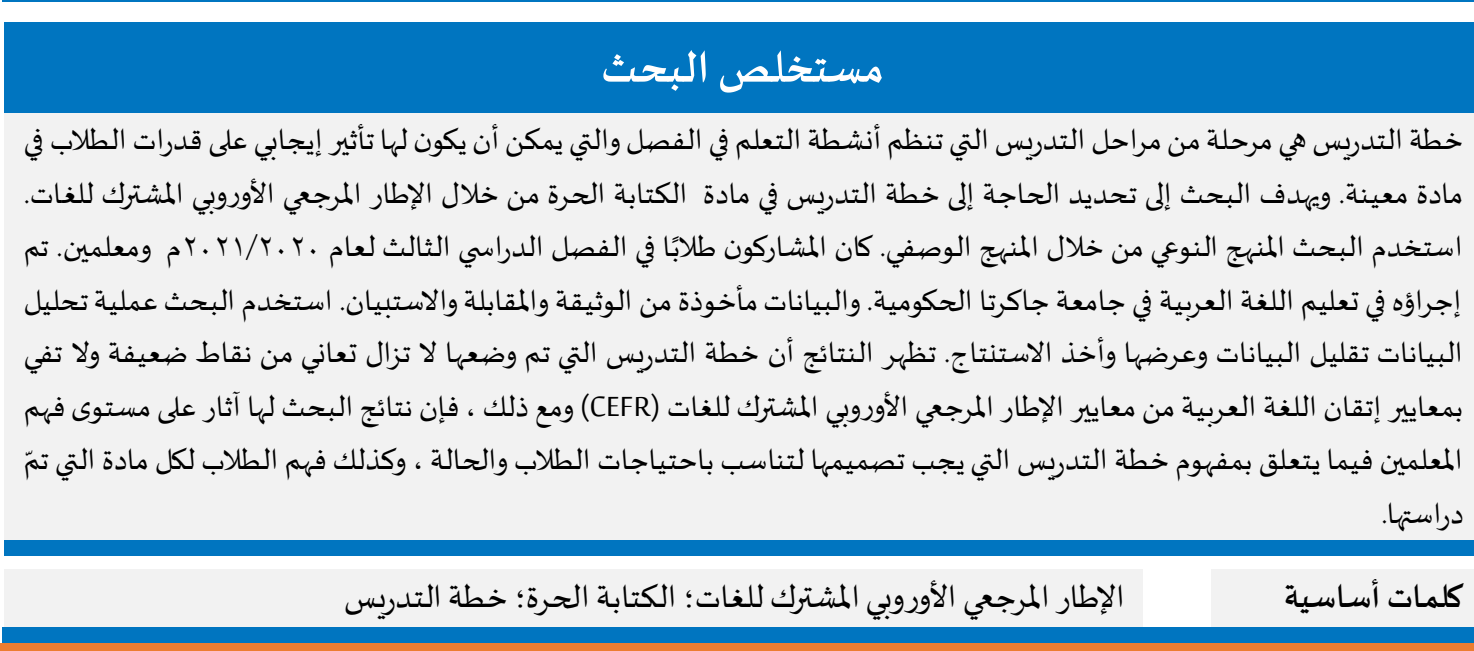

Please cite this article as Hakim, M. K. bin A., Setiadi, S., Tajuddin S., and Yani, A. (2021). Lesson Plan Needs for Arabic Essay Writing (Kitabah Hurrah) Using Common European Framework of Reference for Language. Izdihar : Journal of Arabic Language Teaching, Linguistics, and Literature, 4(3), 291-302. 


\section{INTRODUCTION}

Arabic has a special character and position compared to Indonesian as the mother tongue of students. This condition is very prospective to create fun learning and teaching (Wekke, 2017). Different backgrounds will cause different perspectives in learning Arabic (Tajuddin et al., 2019). So, the learning has to design using the relevant curriculum. The implementation of learning at the university is inseparable from the curriculum design that is relevant to the conditions of the development of science, technology, and industrial needs. The curriculum applied must be designed by the lecture, so that it can meet the needs of students (M Prendergast, 2018; Priestley, 2011).

In Indonesia, the government has made curriculum improvements every period to improve the quality of education and is also relevant to current global conditions. Each country has a different concept of curriculum needs for education. Kenya is designing a new curriculum, themed Competency-Based Curriculum (M'mboga Akala, 2021). In Indonesia, the government has designed the 2013 curriculum that is relevant to global demands. Meanwhile, at the tertiary level, the curriculum must be able to produce globally competent graduates. Universities around the world have initiated comprehensive reviews of curricula and introduced new strategies to change the university's approach to learning and teaching from a teacher-centered orientation to a more student-centered orientation (Mok, 2010).

There is a lot of international rhetoric around the need for national curricula to reflect changes taking place in the world outside of schools. This raises the question of what a quality curriculum should draw like in the age of technology, and the equally challenging issue of how to achieve the changes needed in schools for such a curriculum to be realized (Twining et al., 2020). So, the consequence of globalization as a whole is not the entry of new elements into the curriculum as a forum, but the reformation and relocation of the curriculum (Dale, 2010). So, academics must consider their capabilities to equip our generation with the latest knowledge and skills to face the realism of the future. Universities are required to improve their educational approaches and methods (Ellahi et al., 2019). Especially in the era of the Covid-19 pandemic, the curriculum in the process of providing education must be adapted to the situation (Cahapay, 2020).

The success of curriculum implementation to achieve educational goals can be seen in the success of teaching and learning process activities. Therefore, the learning process must be well designed and clear on the syllabus. The designed syllabus has particular relevance for foreign language education (Rahimpour, 2010). As we know that the form of the syllabus plays a key role in setting the level of specification, locus of control and authority required (Woods et al., 2010). Lecturers can control for learning activities in the classroom more sequentially as stated in the lesson plan as a form of elaboration of the syllabus. Often the design of the lesson plan is not by the needs of students in the classroom. Whereas learning planning made from experience has a positive impact on students (Gülten, 2013). Iqbal et al. (2021) concluded that theory- 
based lesson plans, classroom seating arrangements, monitoring of classroom activities, and teaching experiences are very important for designing and implementing lesson plans in the classroom. Lectures must be able to construct and measure general and specific planning decisions that are relevant to adaptive teaching and appropriate to the cognitive level of the study group (König et al., 2020). Thus, lesson planning is an important part of education and indicates the path the lecture will follow throughout the lesson. Due to the time and dedication of lesson planning and its importance in the teaching and learning process, understanding and recognizing lectures' cognitions when planning at various stages of their careers is necessary (Contreras et al., 2020).

In several previous studies, it is known that lesson planning has a very important position, not only in achieving learning and educational goals but also in graduates' competencies. Each lesson plan should be assessed according to the level of the study group. As in learning to write Arabic essays, from the results of the evaluation of learning outcomes, the syllabus used and lesson plans in the 2019-2020 academic year as well as interviews with 2 Arabic essay writing classes at the end of the semester. It shows that essay writing learning activities are still not according to the needs of students and current challenges. Some materials are still considered monotonous, the use of learning media is still small and has not been used multimedia technology.

In addition, the problem obtained from the observations on the lesson plan document in writing Arabic essays is that the lecturer has not made regular improvements to the lesson plan by the data on student needs and global Arabic learning. This means that the improvement of the lesson plan has been carried out according to the lecturer's perspective and has not developed a framework for the current needs of the industrial world so that the desired learning outcomes for graduates are still oriented to local needs. The lesson plans that have been made should be by the needs of the development of globalization both for the needs of the industrial world.

From these findings, it is necessary to improve lesson plans that can meet student needs, global challenges and also the achievement of educational goals in the Arabic Language Education study program. So, needs to do research activities are carried out as a solution to meet the needs of lesson plan design using the basis of the Common European Framework of Reference for Languages (CEFR). CEFR is the basis for the design of the lesson plan framework because, from previous studies, it is known that the design of lesson plans using the CEFR basis has not been widely studied for learning to write Arabic essays. Moreover, CEFR as an internationally recognized standard describes language proficiency. CEFR is widely recognized throughout Europe and is becoming increasingly common worldwide. The last few years have seen a shift in the paradigm of language teaching and learning with the introduction of the Common European Framework of Reference for Languages (CEFR). In Spain, the CEFR has been applied to Chinese in the same standard way as any other language (Casas-Tost \& Rovira-Esteva, 2014).

Please cite this article as Hakim, M. K. bin A., Setiadi, S., Tajuddin S., and Yani, A. (2021). Lesson Plan Needs for Arabic Essay Writing (Kitabah Hurrah) Using Common European Framework of Reference for Language. Izdihar : Journal of Arabic Language Teaching, Linguistics, and Literature, 4(3), 291-302. DOI: https://doi.org/10.22219/jiz.v4i3.18443 
Thus, the purpose of this study is to identify the need for designing lesson plans in the Arabic essay writing course based on the Common European Framework of Reference for Languages (CEFR). The results of this study are expected to be used as a guide in designing lesson plans for writing courses or other Arabic.

\section{METHOD}

The research used a qualitative approach through the descriptive method. It identifies some phenomenon in the field that was appropriate with the fact (Creswell, 2012). It means that this study did to know the need to make a lesson plan using the common European framework of reference. It was conducted in Arabic Language Education at Universitas Negeri Jakarta. Participants are a lecture $(F=3$ and $M=2)$ and students $(F=27$ and $M=25)$ in the $3^{\text {rd }}$ semester of $2020 / 2021$. They are taken using a random sample. They fill the questionnaires to know the needs of lesson plan design in essay writing subjects.

Instrument of study related to the data collecting process. This study has several data, there are; 1) the document is taken from the curriculum, lesson plan, the result of the learning process evaluation in the previous semester. 2) The interview is done by the lectures and students in Arabic language education in grade 3. They are asked what is related to the concept of lesson plans for essay writing learning. 3) The questionnaire is used to know the lesson plans' needs about Arabic essay writing subject which is relevant with the context. The questionnaire is arranged using Nation and Macalister concept that 4 aspects in lesson plan part. They are goals, content, format and presentation, and evaluation (Nation \& Macalister, 2010). Data analysis uses three steps, they are data reduction, data display, and taking a conclusion (Miles \& Huberman, 1994). The study involves the judgment expert and peer assessment to get data validity. After that, the data is described in percentage and narration analysis.

\section{RESULTS \& DISCUSSION}

The results of the analysis of the syllabus documents that have been used so far concluded that the Arabic essay writing syllabus does not yet have standardized competencies that refer to the Common European Framework of Reference for Language. Arabic learning at CEFR is not only focused on the Nahwu principles as a science or practice, but also on other competencies that must be included in the learning (Nurdianto et al., 2020). The concept of learning outcomes has not yet been developed to meet international standards. This means that the context of learning to write Arabic used is still narrow, so that students can not apply Arabic essay writing skills in the reality of their daily lives. 
The ability to write Arabic essays of international standard is very important in supporting students' Arabic proficiency. Therefore, the CEFR becomes the basis for this research to determine the level of competence needed for writing Arabic essays by the competencies expected by students and also international standards. In addition, the writing competence made is not by Chomsky's Transformational Linguistic Theory which has a role in the achievement of writing skills (Wargadinata et al., 2021)

While the results of the data analysis of the questionnaires that have been filled out by students are presented in the following table.

Table 1. Students Perception on Lesson Plan Needs for Arabic Essay Writing Learning

\begin{tabular}{|c|c|c|c|c|}
\hline Aspect & $\begin{array}{l}\text { Very } \\
\text { Often }\end{array}$ & Often & $\begin{array}{l}\text { Some } \\
\text { times }\end{array}$ & Never \\
\hline $\begin{array}{l}\text { Goal: Arabic essay writing practice } \\
\text { goals }\end{array}$ & $8,6 \%$ & $31,4 \%$ & $60 \%$ & $0 \%$ \\
\hline $\begin{array}{l}\text { Content } \\
\text { a. Personal letter (الرسالة الشخصية) }\end{array}$ & $0 \%$ & $14,3 \%$ & $80 \%$ & $5,7 \%$ \\
\hline b. Formal letter (الرسالة الرسمية) & $0 \%$ & $74,3 \%$ & $25,7 \%$ & $0 \%$ \\
\hline C. Speech text (نص الخطابة) & $2,9 \%$ & $48,6 \%$ & $48,6 \%$ & $0 \%$ \\
\hline d. Report (تقرير) & $11,4 \%$ & $62,9 \%$ & $28,6 \%$ & $0 \%$ \\
\hline e. Book review (مراجعة الكتاب) & $2,9 \%$ & $51,4 \%$ & $45,7 \%$ & $2,9 \%$ \\
\hline f. Scientific writing (مقالة علمية) & $17 \%$ & $66 \%$ & $17 \%$ & $0 \%$ \\
\hline g. Writing summary (تلخيص) & $0 \%$ & $11,4 \%$ & $88,6 \%$ & $2,9 \%$ \\
\hline h. Free writing (كتابة حرة عن موضوع معين). & $0 \%$ & $31,4 \%$ & $71,4 \%$ & $0 \%$ \\
\hline $\begin{array}{l}\text { Format and presentation } \\
\text { a. Repetition writing topics for } \\
\text { individual and group task }\end{array}$ & $8,6 \%$ & $28,6 \%$ & $62,9 \%$ & $2,9 \%$ \\
\hline $\begin{array}{l}\text { b. Learning sources } \\
\text { Evaluation: peer assessment and } \\
\text { lecture assessment }\end{array}$ & $\frac{6,6 \%}{6,6 \%}$ & $\frac{25,7 \%}{33,4 \%}$ & $\begin{array}{l}60 \% \\
60 \%\end{array}$ & $\begin{array}{l}8,6 \% \\
2,9 \%\end{array}$ \\
\hline
\end{tabular}

Table 1 shows some findings that related to the needs of lesson plan design in Arabic essay writing. In terms of format and presentation of Arabic writing learning, students need a theme with the same topic. This form of repetition of writing topics explains that students can improve writing that has been done independently or in groups. While the concept of learning resource needs, students need a plan that can be direct students to explore various knowledge related to the ability to write Arabic essays from various learning sources. In the aspect of objectives, it shows that students have not seen the achievement of the goals of essay writing skills that are by their wishes in the lesson plan. In the material aspect, various material content that are difficult to learn so far in the Arabic essay writing course is presented. The result of the evaluation aspect shows that it is carried out using 2 processes, namely peer 
assessment aimed at student activities. Meanwhile, the lecturer assessed the overall results of the writing both in terms of grammar, meaning and topic.

From the distribution of the questionnaires, it is concluded that the personal letter material is easily understood by students. While formal letter material, students often find it difficult to understand each part of the use of standard vocabulary. In speech text, some students are easily to understand the development of speech texts and some students find it difficult to understand speech texts. Writing an Arabic essay in the form of a report is also difficult for students, as is the case for writing book reviews and writing scientific papers. In contrast for making book reviews and reports which are still considered to require a variety of activities, writing summaries are as easy as an essay writing activity for students.

The results of the questionnaire data analysis aimed at the lecturers concluded that the teaching materials developed from the ten questions asked were the teaching materials developed to write scientific papers (مقالة), write official letters (الرسمية الرسالة), write journal articles (الرسال) (تلمية المجلة مقالة); write a report (تقرير); write personal letters (الشخصية الرسالة); write a summary (تلخيص); write a book review (الكتاب مراجعة); write a free essay on a specified topic (كتابة) (لتخاب). Of all these questions, the two lecturers answered necessary and very necessary, two materials were answered unnecessary, namely writing speech texts (الخطابة نصا (اخصار)) and writing news texts (الأخبار نص). This shows that the 8 materials need to be included in the development of teaching materials.

The finding shows that students and lectures need the activities of Arabic essay writing that referred to the language assessment standard as CFER. The Figure 1 is the framework of lesson plan needs for Arabic essay writing that is described in this research;

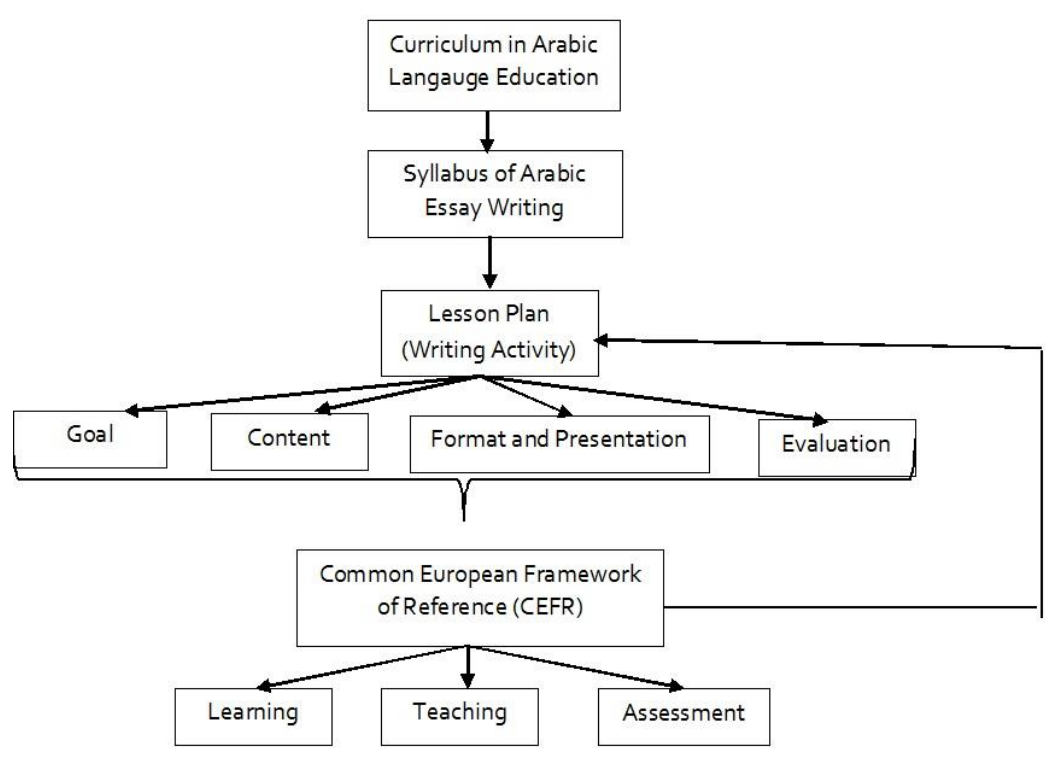

Figure 1. The Framework of Lesson Plan Needs for Arabic Essay Writing 
The results of interviews with students and lecturers concluded that so far students have been given free writing activities according to their choice of topics. However, these activities did not go well because the results of student essays were still low on hat alignment, grammar and meaning. Meanwhile, the results of the questionnaire data analysis showed that students could participate in free essay writing activities on the specified topic. These findings indicate that there is a difference in the perception of students' writing results with students' perceptions of free writing activities. While the results of a more in-depth interview analysis of these findings conclude that freewriting, which is interpreted by students, is related to pouring out ideas or learning experiences that they have so far. As for the lecturers, this perception appears more on the written content only. Thus, lecturers must carry out deeper development of activities related to free writing activities, both on topics that have been determined or not. Activities that can be aligned with students' understanding of the essence of Arabic essay writing material. The students' activity in the writing is not only process and product-oriented, but also it refers to the learning theoretical concept (Hakim \& Hakim, 2019). Olson described the process as referring to the unification of ideas from beginning to end and becoming an article ready to be published, this process is useful for novice writers. Because writing has many steps, not just based on the logic that evokes a different imagination (Linse, 2005).

The results of the analysis of the syllabus and lesson plan documents for Arabic essay writing courses also conclude that the weaknesses found in the lesson plan design have been seen in the standard of language learning activities as widely used in Europe, namely CFER. The results of interviews with lectures also show that so far the lessons made only refer to the objectives to be achieved from the curriculum design. According to them, CFER can be aligned with the curriculum framework of universities and study programs including adjustments to the framework of learning, teaching and language assessment. In this study the syllabus can produce the best learning outcomes for students, the education system must adopt the principles of its selection based on student needs (Bazyar et al., 2015). Moreover, in the era of advances in technology and knowledge, the process of providing education must be able to meet the needs of students and globally.

The millennial era which is full of challenges and uncertainty requires educational institutions to design their education based on real needs in the field that can produce human resources who have the competence of attitudes, knowledge and skills, to prepare for this, the syllabus plays an important role because it is one of the stages of the curriculum, to answer what to learn to deal with this problem. Competence can be interpreted as knowledge, skills, and abilities that are mastered by someone who has become part of him (Nuraini \& Nuraini, 2019). Understanding the function of the syllabus as a charter document in genre ecology helps underscore the importance of the syllabus as a regulatory document that can have a significant impact on students (Jones, 2018). It means that the curriculum has been designed as lectures' innovation (Looi et al., 2014)

Please cite this article as Hakim, M. K. bin A., Setiadi, S., Tajuddin S., and Yani, A. (2021). Lesson Plan Needs for Arabic Essay Writing (Kitabah Hurrah) Using Common European Framework of Reference for Language. Izdihar : Journal of Arabic Language Teaching, Linguistics, and Literature, 4(3), 291-302. DOI: https://doi.org/10.22219/jiz.v4i3.18443 
In this study, the syllabus is directed at understanding the series of activities carried out by students in writing Arabic essays which are described in detail in lesson planning. So, the lesson plan is a map of each learning instruction that must be studied by students. In the lesson plan, the lectures explains the learning objectives, a series of learning activities from the learning strategies used, and the learning evaluation stage. Thus, the lesson plan consists of three main components, namely 1) student learning objectives, 2) learning/teaching activities, 3) strategies to check student understanding. Each lesson plan provides theoretical information and creative activities for practice. It is an extract taken from the course syllabus which can be said as an example of a lesson plan (Kuş̧̧u \& Ünlü, 2015). The lesson plans are also intended for presentation, practice and production. In each phase of the plan, authentic materials are presented that are relevant to current conditions.

The CEFR is the guideline used to describe the achievement of foreign language students across Europe (Sudaryanto \& Widodo, 2020; Pastor \& Guillot, 2015). Thus, the concept of a lesson plan can describe learning objectives according to the level of competence that must be possessed by students. The CEFR is increasingly being used as the preferred framework for language proficiency assessment at universities across Europe. However, to achieve the consistent assessment, socialization and standardization are very important (Haines et al., 2013). It also used in Romania to assess the foreign language proficiency of technical students through various training programs (TănaseRobescu \& Pop, 2010)

\section{CONCLUSIONS}

The finding data concluded that students' answers about materials that were needed in teaching materials were: writing scientific papers (لمية مقالة) 74.3\%, writing official letters (الرسمية الرسالة) 68.6\%, writing journal articles 6ق) 60\%; while the materials needed are: writing a personal letter (الشخصية الرسالة) 74.3\%; write a summary 65.7\%; writing book reviews (الكتاب مراجعة) 54.3\%; write free essays on a specified topic (كتابة) 54.3\%. This shows that students need 8 materials out of 10 materials offered to them. While the materials that they do not need because they get the smallest percentage, namely: writing speech text (نص 48.6\% and writing news text (الخطابة) gets 42.9\%. Each material needed is related to writing activities for students. The problem of designing learning plans should be able to meet the standard values in the assessment of language competence, as described in the CEFR. Thus, the findings on the unequal mastery of the material between the perceptions of students and lectures can be resolved in a series of essay writing activities in the lesson plan.

This research is still limited to the analysis of the need to design a lesson plan for the Arabic essay writing course using the standard framework from the CEFR. However, the results of this study have implications for the understanding of lectures related to learning to write activities in a lesson plan that must be 
designed according to the student's understanding and needs. Moreover, today's global challenges demand the achievement of foreign language mastery competence. Thus, this research can still be developed on the explanation of the strategy model that must be used for learning to write Arabic essays that are relevant to the CEFR framework, so that the level of competence that students want to achieve becomes clearer in the lesson plan.

\section{ACKNOWLEDGMENT}

The authors would like to express their gratitude to the Universitas Negeri Jakarta, especially Language and Art Faculty for funding this research 2021 until finished and can be published in the journal. We hoped that this article can be as guide for arranging the material and lesson in Arabic writing learning at State University Jakarta.

\section{BIBLIOGRAPHY}

Bazyar, Z., Dastpak, M., \& Taghinezhad, A. (2015). Syllabus design and needs analysis of students in educational system. Australian International Academic Centre, 6(4), 2203-4714. https://doi.org/10.7575/aiac.alls.v.6n.4p.162

Cahapay, M. B. (2020). Rethinking education in the new normal Post-COVID-19 era: A curriculum studies perspective. Aquademia, 4(2), ep20018. https://doi.org/10.29333/AQUADEMIA/8315

Casas-Tost, H., \& Rovira-Esteva, S. (2014). New models, old patterns? The implementation of the common european framework of reference for languages for Chinese. Linguistics and Education, 271), 30-38. https://doi.org/10.1016/J.LINGED.2014.07.001

Contreras, K., Arredondo, C., Díaz, C., Inostroza, M. J., \& Strickland, B. (2020). Examining differences between pre- and in-service teachers' cognition when lesson planning. System, 91, 102240. https://doi.org/10.1016/J.SYSTEM.2020.102240

Creswell, J. W. (2012). Research, educational planning, conducting, and evaluating quantitative and qualitative research. In P. A. Smith \& C. Robb (Eds.), Pearson (4th ed.).

Dale, R. (2010). Globalization and curriculum. International Encyclopedia of Education, 312-317. https://doi.org/10.1016/B978-0-08-044894-7.00049-X

Ellahi, R. M., Ali Khan, M. U., \& Shah, A. (2019). Redesigning Curriculum in line with Industry 4.0. Procedia Computer Science, 151, 699-708.

Please cite this article as Hakim, M. K. bin A., Setiadi, S., Tajuddin S., and Yani, A. (2021). Lesson Plan Needs for Arabic Essay Writing (Kitabah Hurrah) Using Common European Framework of Reference for Language. Izdihar : Journal of Arabic Language Teaching, Linguistics, and Literature, 4(3), 291-302. DOI: $\underline{\text { https://doi.org/10.22219/jiz.v4i3.18443 }}$ 
https://doi.org/10.1016/J.PROCS.2019.04.093

Gülten, A. Z. (2013). Am I planning well? teacher trainees' voices on lesson planning. Procedia - Social and Behavioral Sciences, 93, 1409-1413. https://doi.org/10.1016/J.SBSPRO.2013.10.053

Haines, K., Schmidt, N., Jansma, P., \& Lowie, W. (2013). Embedding the CEFR in academic writing assessment. Dutch Journal of Applied Linguistics, 2(1), 77-91. https://doi.org/10.1075/DUJAL.2.1.08HAI

Hakim, M. K. bin A., \& Hakim, M. K. bin A. (2019). Needs analysis of Arabic guided writing material using task-based learning. Jurnal Al Bayan: Jurnal Jurusan Pendidikan Bahasa Arab, 11(2), 281-304. https://doi.org/10.24042/albayan.v11i2.5263

Iqbal, M. H., Siddiqie, S. A., \& Mazid, M. A. (2021). Rethinking theories of lesson plan for effective teaching and learning. Social Sciences \& Humanities Open, 4(1), 100172. https://doi.org/10.1016/J.SSAHO.2021.100172

Jones, N. N. (2018). Human centered syllabus design: positioning our students as expert end-users. Computers and Composition, 49(1), 25-35. https://doi.org/10.1016/J.COMPCOM.2018.05.002

König, J., Bremerich-Vos, A., Buchholtz, C., Fladung, I., \& Glutsch, N. (2020). Pre-service teachers' generic and subject-specific lesson-planning skills: On learning adaptive teaching during initial teacher education. European Journal of Teacher Education, 43(2), 131-150. https://doi.org/10.1080/02619768.2019.1679115

Kuşçu, S., \& Ünlü, S. (2015). Teaching translation: A suggested lesson plan on translation of advertising through the use of authentic materials. Procedia Social and Behavioral Sciences, 199, 407-414. https://doi.org/10.1016/J.SBSPRO.2015.07.526

Linse, C. T. (2005). Practical English Language Teaching Young Learners. McGraw Hill.

Looi, C. K., Sun, D., Seow, P., \& Chia, G. (2014). Enacting a technology-based science curriculum across a grade level: The journey of teachers' appropriation. Computers and Education, 71, 222-236. https://doi.org/10.1016/j.compedu.2013.10.006

M'mboga Akala, D. B. (2021). Revisiting education reform in Kenya: A case of Competency Based Curriculum (CBC). Social Sciences \& Humanities Open, 3(1), 100107. https://doi.org/10.1016/J.SSAHO.2021.100107

M Prendergast, P. T. (2018). Curriculum reform in Irish secondary schools? A focus on algebra. Journal of Curriculum Studies, 50(1), 126-143.

https://doi.org/10.1080/00220272.2017.1313315 
Miles, M. B., \& Huberman, A. M. (1994). Qualitative Data Analysis; An Expanded Sourcebook. Sage Publication.

Mok, K. H. (2010). Curriculum and globalization: Higher education. International Encyclopedia of Education, 403-410. https://doi.org/10.1016/B978-0-08044894-7.01589-X

Nation, I. S. P., \& Macalister, J. (2010). Language Curriculum Design. Routledge Taylor \& Francis Group,

Nuraini, N., \& Nuraini, N. (2019). Competency-Based Syllabus and Skills-Based Syllabus of Arabic Learning in College. Jurnal Al Bayan: Jurnal Jurusan Pendidikan Bahasa Arab, 11(1), 25-52. https://doi.org/10.24042/albayan.v11i1.2846

Nurdianto, T., Hidayat, Y., \& Wulandari, V. A. (2020). CEFR-Based Arabic Language Learning Competency. Izdihar: Journal of Arabic Language Teaching, Linguistics, and Literature, 3(3), 229-248. https://doi.org/10.22219/JIZ.V3I3.14123

Pastor, A. J., \& Guillot, C. P. (2015). Beyond the CEFR: Towards standardization of language competence recognition in Europe. Procedia - Social and Behavioral Sciences, 178, 146-150. https://doi.org/10.1016/J.SBSPRO.2015.03.171

Priestley, M. (2011). Schools, teachers, and curriculum change: A balancing act? Journal of Educational Change, 12(1), 1-23. https://doi.org/10.1007/s10833-010-9140-z

Rahimpour, M. (2010). Current trends on syllabus design in foreign language instruction. Procedia - Social and Behavioral Sciences, 2(2), 1660-1664. https://doi.org/10.1016/J.SBSPRO.2010.03.254

Sudaryanto, S., \& Widodo, P. (2020). Common European Framework of Reference for Languages (CEFR) dan Implikasinya bagi Buku Ajar BIPA. Jurnal Idiomatik, 3(2), 80-87. https://doi.org/10.46918/IDIOMATIK.V3I2.777

Tajuddin, S., Kamal, M., \& Zuryati, Z. (2019). Arabic Material Development Design for Senior High School. Arabiyat: Jurnal Pendidikan Bahasa Arab Dan Kebahasaaraban, 6(1), 93-107. https://doi.org/10.15408/a.v6i1.10949

Tǎnase-Robescu, D., \& Pop, M. (2010). Developing a common framework for foreign language teaching in Romanian technical universities. Procedia Social and Behavioral Sciences, 2(2), 5630-5634. https://doi.org/10.1016/J.SBSPRO.2010.03.918

Twining, P., Butler, D., Fisser, P., Leahy, M., Shelton, C., Forget-Dubois, N., \& Lacasse, M. (2020). Developing a quality curriculum in a technological era. Educational Technology Research and Development.

Please cite this article as Hakim, M. K. bin A., Setiadi, S., Tajuddin S., and Yani, A. (2021). Lesson Plan Needs for Arabic Essay Writing (Kitabah Hurrah) Using Common European Framework of Reference for Language. Izdihar : Journal of Arabic Language Teaching, Linguistics, and Literature, 4(3), 291-302. DOI: https://doi.org/10.22219/jiz.v4i3.18443 
https://doi.org/10.1007/S11423-020-09857-3/FIGURES/1

Wargadinata, W., Risalah, L. K., Elmi, U., Maimunah, I., \& Mei, S. Y. (2021). Chomsky's Transformational Linguistic Theory in Writing Skill at Islamic Senior High School: Transforming Language Learning Pedagogy. Izdihar: Journal of Arabic Language Teaching, Linguistics, and Literature, 4(2), 127-152. https://doi.org/10.22219/JIZ.V4I2.16490

Wekke, I. S. (2017). Arabic Learning Material of Higher Education Muslim Community North Sulawesi. Dinamika IImu, 17(2), 175-189.

https://doi.org/10.21093/di.v17i2.863

Woods, A., Luke, A., \& Weir, K. (2010). Curriculum and Syllabus Design. International Encyclopedia of Education, 362-367. https://doi.org/10.1016/B978-0-08-044894-7.00058-0 